\title{
The protection of cultural property in armed conflict
}

by Roger O’Keefe

The protection of cultural property in armed conflict has been a matter of legal concern since the rise of modern international law in the sixteenth and seventeenth centuries. What is meant by "cultural property" depends to an extent on the context, since each of the relevant treaties applies to a greater or lesser range of things. In essence, however, the term refers to buildings and other monuments of historic, artistic or architectural significance, to archaeological sites, to artworks, antiquities, manuscripts, books and collections of the same, to archives, and so on. The terminology distinguishes between "immovable" and "movable" cultural property, the labels being self-explanatory. By "protection" is meant, in the wartime context, protection from damage and destruction and from all forms of misappropriation.

$\mathrm{T}$ hree basic points can be made about the protection, by means of international law, of cultural property in armed conflict. None is momentous or profound, but each is a useful corrective to seemingly popular and potentially harmful assumptions. First, states and other past parties to armed conflict have placed more, and more sincere, value on sparing and safeguarding immovable and movable cultural property, at least since 1815, than might be assumed. Next, the international legal protection of cultural property in armed conflict is not a pipe-dream. Finally, the criticism that concern for the wartime fate of cultural property displays callousness to the fate of people is misplaced.

\section{VALUE PLACED ON PROTECTION}

Since the end of the Napoleonic Wars, states and other parties to armed conflict have placed greater value on protecting cultural property than might be assumed. Perhaps it is not saying much, given the seemingly entrenched view that cultural property has always been deliberately attacked and looted in war, or its protection at best ignored. But it is no less true for that.

For a start, states have expended considerable energies on elaborating a demanding and sophisticated body of international rules specifically directed towards the protection of cultural property in armed conflict.

Some of these rules are to be found in the various general conventions on the laws of armed conflict. The 1899 and 1907 Hague Regulations on the Laws and Customs of War on Land, 1907 Hague Convention IX on naval bombardment, 1977 Additional Protocols I and II to the Geneva Conventions, and the 1980 and 1996 Protocols to the Conventional Weapons Convention on mines, booby-traps and other devices all contain specific provisions on cultural property. Conversely, of the general conventions on the protection of cultural property, the 1970 Convention on the Means of Prohibiting the Illicit Import, Export and Transfer of Ownership of Cultural Property contains an article relevant to armed conflict.

Alongside these treaties there have also evolved customary international rules of a criminal nature for punishing wartime mistreatment of cultural property. In the wake of World War One, the draft list of war crimes prepared by the 1919 Preliminary Paris Peace Conference recognised the wanton destruction of cultural property as criminal, and France sought the extradition from Germany of 16 individuals implicated in war crimes of a cultural nature. After World War Two, the Nuremberg tribunal convicted several defendants, chief among them Alfred Rosenberg, of war crimes and crimes against humanity for their roles in the Nazi plunder and destruction of cultural property in the occupied territories to the east. At the other end of the scale of gravity, a French military tribunal at Metz held a German soldier responsible for the destruction of a war memorial and a statute of Joan of Arc in a small town in occupied France. In more recent times, the International Criminal Tribunal for the former Yugoslavia has been vested with jurisdiction over war crimes in relation to cultural property, and has developed a body of relevant authority in cases such as Strugar and Jokić (both dealing with the shelling of the Old Town of 
Dubrovnik) and Plavšić Blaškić, Kordić, Naletilić and Brđanin (all on the devastation of cultural property in Bosnia-Herzegovina). The International Criminal Court has been granted an analogous jurisdiction by the Rome Statute.

Most tellingly, states have adopted several specific conventions on the protection of cultural property in armed conflict, treaties which trace their origins to a 1919 report of the Netherlands Archaeological Society, as reflected in a provision of the 1923 draft Hague Rules on Aerial Warfare and later in the 1938 Preliminary Draft International Convention for the Protection of Historic Buildings and Works of Art in Times of War. In 1935, the Seventh International Conference of American States concluded the Treaty on the Protection of Artistic and Scientific Institutions and Historic Monuments, known as the Roerich Pact, applicable to both war and peace. The Pact is still in force among 11 American states, although it is for all intents and purposes a dead letter. Far more significantly, in 1954 states adopted the Hague Convention for the Protection of Cultural Property in the Event of Armed Conflict, along with its First Protocol. The Convention was updated and added to in 1999 by the adoption of a Second Protocol. The Convention currently has 166 states parties, the First Protocol 93 and the Second Protocol 44. This treaty regime remains the cornerstone of the international legal protection of cultural property in armed conflict.

All these normative efforts can be summed up in the following basic rules, applicable to international armed conflict (including belligerent occupation) and noninternational armed conflict alike, consonant with customary international law and non-exhaustive. To begin with, it is prohibited to attack cultural property unless it makes an effective contribution to military action and its destruction offers a definite military advantage. It is also illegal to attack a military objective, such as a tank, a military headquarters or a munitions factory, if this cannot be done without inflicting on nearby cultural property damage out of proportion to the military advantage anticipated. The demolition of cultural property under a party's own control is forbidden too unless military necessity imperatively requires it. It is further prohibited to use cultural property for military purposes unless there is no other feasible way to obtain a similar military advantage. All forms of theft, pillage, misappropriation, confiscation or vandalism of cultural property are similarly unlawful. Parties to an armed conflict are required to prohibit, prevent and, if necessary, put a stop to all such acts. They are also forbidden to seize or requisition cultural property situated in the territory of an opposing party. Individuals responsible for intentional attacks on, other destruction of, or plunder of cultural property may be punished for war crimes, and widespread or systematic destruction or plunder of cultural property can qualify as a crime against humanity. As specifically regards occupied territory, an occupying power must prohibit and prevent any illicit export, other removal or transfer of ownership of cultural property, and must as far as possible support the competent authorities of the territory in safeguarding and preserving cultural property.

Where the 1954 Hague Convention and/or its Protocols apply, additional obligations arise, and special institutions and mechanisms for the enforcement of these obligations come into play. For example, states parties must prepare in time of peace for the safeguarding of cultural property situated within their own territory against the foreseeable effects of an armed conflict, by taking such measures as they consider appropriate. Such measures include, as appropriate, the preparation of inventories, the planning of emergency measures for protection against fire or structural collapse, the preparation for the removal of movable cultural property or the provision of adequate in situ protection of such property, and the designation of competent authorities responsible for the safeguarding of cultural property. Under the Second Protocol, a state party in occupation of the whole or part of the territory of another must prohibit and prevent any archaeological excavation in the occupied territory, save where this is strictly required to safeguard, record or preserve cultural property. The same applies in respect of any alteration to, or change of use of, cultural property which is intended to conceal or destroy cultural, historical or scientific evidence. Over and above the general rules which apply to all cultural property, the Convention and Second Protocol provide for optional regimes of "special" and "enhanced" protection respectively, providing in theory for a higher standard of protection in respect of a narrower range of property. The Second Protocol embodies a detailed regime of war crimes provisions. The Convention provides for elaborate (and in practice dysfunctional) implementation and compliance mechanisms, and the Second Protocol has created both an intergovernmental Committee for the Protection of Cultural Property in the Event of Armed Conflict and a Fund for the same.

Nor has the wartime protection of cultural property been merely on paper. Since 1815, good will, conscientiousness and a broad consensus that cultural property should, where at all possible, be spared in armed conflict have figured more prominently than might be thought. Where such qualities have been lacking, fear of the consequences, especially in terms of public opinion, has tended to compel compliance. Indeed, the historical record shows that malicious destruction and plunder of cultural property by armed forces and flagrant disregard for its wartime fate have been exceptions over the past 200 years - devastating and not uncommon exceptions, but exceptions all the same, and condemned by other states.

Of course, any argument to this effect runs up hard against World War Two. But the first point to be made is that, leaving aside the Nazis' depredations in the occupied territories to the east, the destruction of cultural property 
during the war was mostly not prohibited by international law as it stood at the time, and was rarely premeditated or nonchalant. This includes, for the most part, the Allies' strategic bombing campaign over Germany, in relation to which the UK's secretary of state for air told the Commons in 1942, it would seem sincerely:

Monuments of art and antiquity are the common heritage of all mankind. We do not deliberately destroy them, but it is our policy to restore that greater heritage of mankindfreedom - and to do that we must and will destroy the enemy's means of making war - his defences, his factories, his stores and his means of transportation, wherever they may be found.

This should not be taken to mean that each and every Allied strategic air raid was lawful. In many instances, for example the devastation of Dresden and the US raids on Japan from late 1944, the already-elastic notion of a military objective was stretched very arguably beyond breaking point. But rarely were such acts in wilful defiance of the law. The same goes for other notorious examples of the destruction of cultural property during the war, such as the tactical aerial attack on the Benedictine abbey at Monte Cassino and Field Marshal Kesselring's swingeing demolitions in Florence. The genuine military necessity for either action must be seriously in doubt, but neither was an act of outlawry. One exception to this pattern was the firebombing of Lübeck (although the town was chosen not for its history as such but for its wooden construction), which in turn led by way of retaliation to the Germans' "Baedeker raids" on Exeter, Bath, Norwich, York and Canterbury, undertaken with the perhaps-rhetorical intention of destroying every building in England marked with three stars in the famous guidebook.

Conversely, World War Two witnessed conspicuous acts of cultural solicitousness. Despite being the second capital of the Axis and the focal point of the railway lines from southern to northern Italy, Rome was spared Allied bombing until July 1943 in explicit recognition of its cultural significance; and when it was bombed, special techniques were used and precautions taken to avoid hitting cultural property. It was a similar story with Florence and Siena. As regards Japan, although many of the US raids were of questionable legality, Kyoto and Nara were spared on cultural grounds. In the land war, Monuments, Fine Arts and Archives ("MFA\&A") officers accompanied US forces throughout Europe, advising commanders as to the location of and care to be given to cultural property - a practice imitated by the British, for example in Libya. General Eisenhower's General Order No 68 of 29 December 1943, on the preservation of historic monuments in the mainland Italian campaign, emphasised the care to be taken to spare cultural property, and promulgated rules to this end. The order reiterated in more emphatic terms one to the same effect during the Sicilian campaign, and was followed by a directive of 26 May 1944 for western and central Europe, as well as by
Title 18 ("Monuments, Fine Arts and Archives") of the Military Government Regulations for the US zone in occupied Germany. For its part, the German Kunstschutz or art protection corps took considerable pains to safeguard cultural property in southern and western Europe (although its efforts were undermined by the Einsatzstab Rosenberg, a special unit for the plunder of works of art, by the Special Purposes Battalion of the Waffen SS of the Ministry of Foreign Affairs, directed by von Ribbentrop, by the archaeological corps of the Ahnenerbe, the SS's special research division, and by operatives working on the personal behalf of Göring and Bormann respectively). In the same vein, Kesselring insisted on abandoning Rome without a fight, and without engaging in the routine military practice of demolitions to hinder pursuit. (The first Allied soldier to enter Rome the following morning was a US MFA\&A officer, in accordance with a plan drawn up six months before.) Similarly, the commander of occupied Paris, General von Choltitz, deliberately delayed carrying out an initial order to destroy all the bridges over the Seine, and eventually ignored Hitler's command to defend the city "stone by stone", choosing instead to surrender without a fight.

In subsequent conflicts too, the international rules on the protection of cultural property in armed conflict have by and large been observed. For example, prior to the air and sea-launched missile strikes which ushered in the 1991 Gulf War and which accompanied the invasion of Iraq in 2003, and prior to the aerial campaign over Yugoslavia in 1999, US military planners, in consultation with civilian experts, identified and placed on a special "no target" list significant cultural property in the countries in question. During the first of these conflicts, when Iraq positioned two fighter aircraft next to the ancient ziggurat at Ur, Coalition commanders decided not to attack them after weighing the value of their destruction against the risk of damage to the historic site. Similarly, when in 2002 a large number of armed Palestinian militants took up positions inside the Church of the Nativity in Bethlehem, the Israel Defence Forces refrained from an assault on the site, the standoff eventually being resolved through international good offices.

It is best, however, not to overdo the point. Appalling exceptions to the overall historical pattern of compliance and good faith since 1815 are not hard to find: the Nazis' colossal devastation and seizure of the cultural heritage of the occupied territories to the east, Iraq's plunder of Kuwaiti cultural institutions in 1990, the shelling of the Old Town of Dubrovnik in 1991 and 1992, the systematic razing of places of worship, many of them centuries old, and other historic landmarks such as the Old Bridge at Mostar during the war in Bosnia-Herzegovina, and the failure of US forces to guard Iraqi cultural institutions during the 2003 invasion, to name a few. Moreover, it is cold comfort that much of the destruction of cultural property during World War Two was not prohibited by the 
laws of war as they then stood. But a frank recognition of these points does nothing to undermine the essential truth of the conclusion that states have made a greater effort since the end of the Napoleonic Wars to spare cultural property in armed conflict than seems to be assumed and, indeed, that such efforts have in practice been the norm.

\section{UNREALISTIC?}

Contrary to common assumption, the protection of cultural property in armed conflict by means of international law is not a hopelessly unrealistic proposition.

The greatest cause of the wartime destruction of cultural property since 1815 has been its incidental damage in the course of bombardment of otherwise lawful targets. Such destruction reached its dreadful apogée in the World War Two Allied strategic bombing campaigns over Germany and Japan. But the signal failure of international law to prevent the devastation from the air of much of these countries' cultural heritage was in many ways anomalous, a function of a specific moment in both the laws of armed conflict and military technology: legally, the classical rules on bombardment had been rendered obsolete but the regime that would come to replace them was still underdeveloped; technologically, the massive increase in the explosive yield of ordnance and the capacity to deliver it from the air had not been adequately matched by advances in the precision with which it could be targeted. Thanks, however, to crucial legal and technological developments since 1945, today there is a greater possibility than ever before of sparing cultural property from damage and destruction in war.

The laws of war codified in the 1907 Hague Regulations had permitted recourse to bombardment only against "undefended" localities. If, on the other hand, a city or town was defended, it was not just its defences that could be bombarded: whatever morality may have said, no positive rule of international law forbade bombardment of civilian quarters as long as all necessary steps were taken to spare, as far as possible, cultural property, hospitals and the like. And the qualified rule on sparing cultural property did not in practice amount to much, since it was difficult to spare cultural property when everything around it was a lawful object of attack, and bombardment was not prohibited where the foreseeable damage to cultural property outweighed the military advantage to be gained. In the final analysis, the fate of cultural property hung in the course of bombardment on the concept of a "defended" town. But World War One exposed the inadequacies of this concept in the age of long-range artillery and aircraft. With the lines on the Western Front stretching from Flanders to Verdun and beyond, every urban centre behind them could be captured only by fighting and was therefore, in effect, defended. Moreover, full of troops, making them defended in a second sense. They were usually also within range of defensive artillery or aerial counteraction. The assumption, therefore, was that virtually every single city and town was liable to bombardment, and in the absence of any positive restraint on bombarding civilian districts in defended towns, all civilian property, except for cultural property and certain protected institutions, was open to attack. As a consequence, even if cultural property situated in a defended town was not itself the object of bombardment, it was often damaged in attacks on surrounding property, as when, in March 1918, a German shell destroyed the nave of the thirteenth-century church of Saint Gervais in Paris, killing 88 people. If such damage was unavoidable in the bombardment of lawful targets, it was not unlawful.

There was general agreement after World War One that the law on bombardment was outmoded, especially as it applied to bombing from the air. As a result, the conceptual foundations of the law were recast. The dichotomy between undefended and defended towns was replaced by the more precise concept of individual military objectives. Any town or city could, in principle, be bombed from the air but bombing was to be restricted to objects whose destruction would deliver a distinct military advantage to the belligerent. But the problem was that an exhaustive list of military and related infrastructural targets, as posited in the 1923 draft Hague Rules on Aerial Warfare, was never binding on states as a matter of treaty law and did not emerge in the interwar years as customary international law. The same went for the rule, also laid down in the draft Hague Rules on Aerial Warfare, that a belligerent was to refrain from bombarding an otherwise-lawful military object if this could not be done without loss of civilian life or damage to civilian property, including cultural property, that was out of proportion to the military advantage anticipated. These shortcomings reaped the whirlwind in World War Two. The definition of a military objective expanded to encompass any object whose destruction would weaken the enemy's capacity to carry on. All civilian industry and infrastructure, and the residential districts where the industrial workforce slept, were viewed as lawful targets, and while targeting the general populace as such was publicly beyond the pale, the latter's terrorisation was, at the very least, an intended by-product of aerial bombardment. The greater the number of military objectives, the greater the risk of incidental harm to cultural property, a risk rendered a virtual certainty by technological limitations. The "Butt Report", delivered to the UK's Bomber Command in 1941, concluded that the smallest targets in Germany operationally feasible at night with the aircraft and highly inaccurate delivery systems available were whole towns, so that although the British government expressed on the outbreak of war "a firm desire ... to preserve in every way possible those monuments of human achievement which are treasured in all civilized countries", it was not thought possible from the 
air. The secretary of state for air explained the policy to the Commons as follows:

We cannot be prevented from bombing important military targets because, unfortunately, they happen to be close to ancient monuments ... The same principles are applied to all centres. We must bomb important military objects. We must not be prevented from bombing important military objects, because beautiful or ancient buildings are near them.

The upshot of all of these considerations was the practice of area bombing, in which multiple, distinct military objectives scattered over an urban concentration were destroyed by levelling the whole concentration indiscriminately. As for the prevailing law, it provided that as long as it was lawful to attack the intended objective, any unavoidable incidental damage to cultural property was subsumed within that lawfulness.

But today the legal and technological climates are crucially different. A generally accepted treaty-based and customary definition limits lawful military objectives to objects which make an effective contribution to military action, as distinct from the enemy's broader capacity to sustain the military effort. The result is far fewer military objectives in the course of whose destruction nearby cultural property will be placed at risk. Even more significantly, in what is probably the single greatest legal advance since 1945 in the protection of cultural property in armed conflict, both treaty and customary international law now embody a restraint on incidental damage to such property. As seen above, it is now unlawful to attack an otherwise-lawful military objective if this cannot be done without incidental damage to cultural property out of proportion to the military advantage anticipated. When it comes to technology, the advent of so-called "smart" ordnance has improved almost beyond belief the accuracy of aerial bombardment, at least at the hands of the military powers most likely to engage in it. All these developments have greatly improved the chances that cultural property will survive war unscathed.

Again, however, it is best to remain sanguine.

There are, in the end, limits to what international law can do to civilise war. No rules will ever stop parties to an armed conflict or individual combatants who, motivated by malice, ideology or arrogance and convinced of their impunity, bear contemptuous disregard for law itself. The Nazis' devastation and seizure of the cultural heritage of the occupied East was a phenomenon beyond the power of law to prevent. The same is probably true of Iraq's plunder of the cultural institutions of Kuwait in 1990, the destruction of historic and religious sites in the former Yugoslavia, the use by armed militants loyal to Moqtada al-Sadr of the Imam Ali mosque as both arsenal and refuge, and former Secretary of Defense Rumsfeld's breathtaking disregard for the security of Iraq's museums and archaeological sites. International law can only have purchase where abiding with international law holds intrinsic value. History shows that international legal compliance mechanisms - weak at the best of times, and even weaker in war-do little to restrain the die-hards.

Moreover, the gravest threat to cultural property during armed conflict today is its theft by private, civilian actors not bound in this regard by the laws of war. The breakdown of order that accompanies armed conflict and the corrupting lure of the worldwide illicit market in art and antiquities continue to drive the looting of archaeological sites and museums in war-zones and occupied territory. The laws of war do not extend to such private acts. And while international law does oblige an occupying power to prevent and put a stop to all this, much and perhaps most looting takes place in the context of noninternational armed conflict, where the rules on belligerent occupation do not apply.

The point to be made, however, is that insofar as the laws of war are capable of modifying behaviour, the rules on the wartime protection of cultural property are as capable as any.

\section{CALLOUS?}

Lastly, the accusation commonly levelled in the context of its destruction that a desire to protect cultural property in war reflects a callousness to human beings is misplaced.

The argument can be rebutted as a matter of formal logic. There is no necessary reason why an interest in the one should mean a disregard for the other. It can also be dismissed for failing to understand the philosophical basis of heritage protection. Cultural property is protected not for its own sake but for the sake of the human beings who draw meaning and pleasure from it. The ultimate end of protecting cultural property is human flourishing.

But there is also a more pragmatic answer. The protection of cultural property in armed conflict is, as history shows, simply impossible without an equal or greater concern for the protection of civilians. If a civilian quarter is targeted, the cultural property in its midst will tend to suffer with it. Conversely, as the inhabitants of Rome, Kyoto and Nara could attest, a concern to spare cultural property from the destructive effects of war can end up saving the lives of the local people.

Ultimately, no matter what legal and practical measures are adopted, war is a threat to cultural property, and the only safe bet is not to wage it.

- This article is taken from a lecture given by the author at the Institute of Advanced Legal Studies on February 15, 2007.

\section{Dr Roger O’Keefe}

Lecturer in Law and Deputy Director of the Lauterpacht Centre for International Law, University of Cambridge; author, The Protection of Cultural Property in Armed Conflict (2006) 